перегляду дидактичного змісту іï парадигми як прикладної науки.

2. Прийняття за концептуальну основу зазначеного перегляду парадигми розуміння природи об'єкта як складної системи взаємопов'язаних елементів, а його оборотного зображення - як системи зображень цих елементів, взаємопов'язаних графічними моделями геометричних зв'язків і відношень між ними, сприяє створенню системної нарисної геометрії як фундаментальної синтетичної науки тому, що вона є геометрією картинного простору, яка досліджує зображальні властивості його елементів, які містять інформацію про позиційні і метричні властивості дійсної форми тих об’єктів, що зображені.

3. Дидактичний зміст нарисної геометрії слугує формально-логічною основою створення системної педагогічної технології iï навчання майбутніх архітекторів, ефективність якої зумовлюється іiі інтегральністю, що сприяє створенню діалектичної взаємодії перцептуального й концептуального образів мислення як основи поступового перетворення буденного мислення першокурсників на конструктивно-композиційне як основу проектного.

Якщо наведені аргументи на користь фундаментальності системної нарисної геометрії $\epsilon$ достатньо переконливими, то перспективами іiї подальшого розвитку $\epsilon$ виконання автором таких науково-педагогічних завдань: 1. Успішний захист дисертації «Система навчання нарисної геометрії майбутніх архітекторів» на здобуття наукового ступеня доктора педагогічних наук. 2. Розроблення навчальної програми 3 системної нарисної геометрії як фундаментальної математичної науки, ії узгодження і затвердження в «Інституті інноваційних технологій в освіті» при МОН України. 3. Написання підручника «Системна нарисна геометрія» з грифом МОНУ для геометрографічної підготовки студентів творчих спеціальностей ВНЗ України.

\title{
Література
}

1. Коменський Ян Амос. Великая дидактика // Я. А. Коменский, Дж. Локк, Ж. Ж. Руссо, И. Г. Пестолоцци. Педагогическое наследие / сост. В. М. Кларин, А. Н. Джуринский. - Москва : Педагогика, 1989. - 416 с. 2. Джеджула О. М. Теорія і методика графічної підготовки студентів інженерних спеціальностей вищих навчальних закладів: дис. ... доктора пед. наук / О. М. Джеджула. - Київ : 2008. - 456 с. 3. Гедзик А. М. Графічна підготовка майбутнього вчителя технологій: [монографія] / А. М. Гедзик. - Умань : Сочінський, 2011. - 306 с. 4. Ковальов Ю. М. Прикладна геометрія : [підручник для ВНЗ] / Ю. М. Ковальов, В. М. Верещага. - Київ : ДІЯ, 2012. - 427 с. 5. Михайленко В. Є. Нарисна геометрія / В. Є. Михайленко, М. Ф. Свстіфеєв, С. М. Ковальов, О. В. Кащенко. - Київ : Вища школа, 2004, - 302 с. 6. Ткач Д. И. Системная парадигма теории обратимых изображений / Д. И. Ткач // Теорія та методика навчання математики, фізики, інформатики. - Вип. VIII. Т. 1. - Кривий Ріг: Видавничий відділ НМетАУ, 2010. - С. 131-139.

УДК 378.091.21:39

Ольга Ткаченко

\section{ДЕЯКІ АСПЕКТИ ПРОБЛЕМИ ФОРМУВАННЯ ТВОРЧОЇ ОСОБИСТОСТІ МАЙБУТНЬОГО ВЧИТЕЛЯ ПОЧАТКОВИХ КЛАСІВ У КОНТЕКСТІ КОМПЕТЕНТНІСНОГО ПІДХОДУ}

Ткаченко О. М. Деякі аспекти проблеми формування творчої особистості майбутнього вчителя початкових класів у контексті компетентнісного підходу.

У статті акцентовано увагу на важливості для сучасного фахівця в галузі початкової 
освіти педагогічної творчості. На основі аналізу змісту педагогічної творчості автором доведена потреба формування в сучасного педагога здатності до етнопедагогічної творчості як елемента етнопедагогічної компетентності, що сприятиме професійній самореалізації вчителя початкових класів в умовах полікультурності сучасного суспільства.

Ключові слова: професійна компетентність педагога, педагогічна творчість, педагогічна майстерність, етнопедагогічна компетентність, етнопедагогічна творчість учителя початкових класів.

Ткаченко О. М. Некоторые аспекты проблемы формирования творческой личности будущего учителя начальных классов в контексте компетентностного подхода.

В статье акцентировано внимание на важности для современного специалиста в области начального образования педагогического творчества. На основе анализа содержания педагогического творчества автором доказана необходимость формирования у современного педагога этнопедагогического творчества как элемента этнопедагогической компетентности, что будет способствовать профессиональной самореализации учителя начальных классов в условиях поликультурности современного общества.

Ключевые слова: профессиональная компетентность педагога, педагогическое творчество, педагогическое мастерство, этнопедагогическая компетентность, этнопедагогическое творчество учителя начальных классов.

Tkachenko O. M. Some aspects of the problem of creative personality formation of a future primary school teacher in the context of competence-based approach.

The article is focused on the importance of pedagogical creativity for a modern specialist in the field of primary education. Based on the analysis of the pedagogical creativity content the author has proved the necessity of ethnopedagogical creativity formation of modern teacher as a part of ethnopedagogical competence that will promote the professional self-fulfillment of primary school teacher in multicultural modern society.

Key words: professional competence of the teacher, pedagogical creativity, pedagogical skills, ethnopedagogical competence, ethnopedagogical creativity of primary school teachers.

Складні соціокультурні процеси в суспільстві, динамічність життя, зумовлені науково-технічним прогресом, вимагають від сучасної людини, яка адаптується в соціумі, інформаційному просторі, на ринку праці, не лише постійного оновлення знань, мобільності в різних ситуаціях, самостійності, а й творчості в ухваленні й реалізації рішень, що підтверджує своєчасність компетентнісного підходу, який більшість дослідників розуміє як спробу узгодити зміст освіти 3 потребами ринку праці, подолати суперечності між навчальною та професійною діяльністю, надати людині змогу жити без перевантаження і стресів.

В умовах глобалізації економіки, міграційних процесів актуалізується проблема етнопедагогічної творчості фахівця в галузі освіти, зокрема й початкової, як елемента його етнопедагогічної компетентності, яка забезпечує самореалізацію особистості як учителя, так і учня в умовах полікультурності.

Педагогічна творчість як предмет вивчення фігурувала в дослідженнях В. Загвязінського, В. Кан-Калика, Н. Кічук, Ю. Кулюткіна, М. Поташника, С. Сисоєвої, Р. Скульського та інших науковців. Творчу діяльність учителя в контексті педагогічної майстерності вивчали І. Зязюн, Л. Крамущенко, І. Кривонос, О. Мирошник, В. Семиченко, 
Н. Тарасевич та інші науковці.

Здобутки етнопедагогіки як науки аналізували у своїх працях Г. Волков, В. Кононенко, В. Кузь, В. Кукушин, Н. Лисенко, В. Мосіяшенко, Є. Приступа, М. Стельмахович, О. Сухомлинська, Є. Сявавко, Т. Усатенко, Г. Філіпчук, М. Хайруддінов. Процеси етнопедагогічної підготовки майбутнього вчителя та формування в нього етнопедагогічної культури досліджували $\quad$ В. Ніколаєв, $\quad$ М. Харитонов. Сутність етнопедагогічної творчості як елемента етнопедагогічної компетентності та ії взаємозв'язок iз професійною самореалізацією вчителя-початкових класів не знайшли належного висвітлення в науковій літературі.

Mema cmammi - обгрунтувати потребу в етнопедагогічній творчості майбутнього вчителя початкових класів як запоруки якісної реалізації вимог компетентнісного підходу в умовах суспільства 3 полікультурним складом населення, 3'ясувати зміст цього виду педагогічної творчості.

Педагогічну творчість у сучасній науці визначено як оригінальне та високоефективне розв'язання вчителем навчально-виховних завдань із проектуванням розвитку особистості учня, застосуванням нестандартних прийомів діяльності, самовдосконаленням самого педагога. Кожен фахівець у галузі освіти покликаний творчо застосовувати знання, прогнозувати свою діяльність, бути здатним до інноваційної, дослідницької діяльності, тим самим підтверджуючи свій професіоналізм. Ідея педагогічної творчості як показника професіоналізму, що виявляється на вищих рівнях педагогічної майстерності, розвивається в межах акмеології та професійної педагогіки Н. Гузій, І. Зязюном, Н. Кічук, А. Марковою, С. Сисоєвою, Н. Тарасевич та іншими науковцями.

Здатність мати творче самопочуття, окриленість у вирішенні професійних завдань, прагнення і спроможність розуміти дітей, нестандартно спілкуватися 3 ними, бачити неповторність кожної дитини, усвідомлювати педагогічну проблему та альтернативно мислити у процесі іiі розв'язання, цілеспрямовано вибирати стандартні й нестандартні методи і прийоми, технології навчання і виховання, здатність до олюднення предметів, натхненності у викладі навчального матеріалу та організації діяльності дітей особливо цінна для фахівця в галузі початкової освіти. Відсутність педагогічної творчості у професійному спілкуванні вчителя початкових класів часто постає причиною пробілів у знаннях учнів та їх небажання вчитися не лише в початковій ланці освіти.

Реалізація творчого потенціалу вчителя початкових класів у професійній діяльності ускладнюється етносоціальною структурою конкретного суспільства, зокрема й українського, до якого, згідно з офіційними даними, входять представники понад 130 етносів. Україну за складом населення відносять до держав 3 поліетнічним складом населення [1, с. 8]. Так, учитель має враховувати, що в етносоціальній структурі країни виокремлюють українську націю та етнічні меншини, до яких відносять такі етнічні групи: росіяни, білоруси, молдовани, болгари, угорці, румуни, поляки, євреї, вірмени, греки, татари, роми, азербайджанці, грузини, німці, литовці, словаки, чехи, естонці тощо. У багатьох етнічних спільнот населення України наявні внутріетнічні групи - субетнічні утворення, які внаслідок різних причин зберігають специфічні риси культури, діалектні особливості мови та самоназву (мікроетнонім). Унаслідок новітніх міграційних процесів, до яких активно залучена Україна, у ній збільшилась кількість ороків, іжорців, ескімосів, в'єтнамців, курдів [1, с. 6-8]. Аналіз етнічного складу населення України свідчить, що представники зазначених ста тридцяти етносів, окрім корінних жителів, переселились на Україну із Західної Європи, різних частин Азії, Америки, Африки, Австралії.

Педагогіка вищої та середної школи. - 2016. - Вип. 47 
Ураховуючи національний склад населення України, новітні міграційні процеси, сучасні вчителі початкових класів можуть реалізувати свій професійний творчий потенціал лише за умови володіння інформацією щодо педагогічних традицій українців, інших етносів світу, не обмежуючись при цьому одним континентом планети. Володіння та оперування такою інформацією актуалізує потребу етнопедагогічної компетентності фахівця в галузі освіти.

Етнопедагогічну компетентність учителя-вихователя ми розглядаємо як різновид педагогічної компетентності, що є динамічним особистісним утворенням фахівця в галузі освіти, яке передбачає опанування педагогом системи етнопедагогічних знань, умінь i навичок кваліфікованого опрацювання надбань світової народної педагогічної культури, урахування актуальності окремих iї елементів у процесі осмислення педагогічної теорії та організації сучасної педагогічної практики, що дає змогу спеціалістові реалізувати гуманістичний підхід до своєї професійної діяльності й оптимально виявити власний творчий потенціал.

Вияв творчого потенціалу педагога в контексті його етнопедагогічної компетентності здійснюється завдяки етнопедагогічній творчості. Цей вид творчості педагога пронизує різні компоненти компетентності, та передовсім у цьому сенсі варто звернути увагу на когнітивний, операційно-технологічний, індивідуально-особистісний (структурні) i гносеологічний, гуманістичний, комунікативний, навчальний, виховний (функціональні) компоненти етнопедагогічної компетентності.

Характер етнопедагогічної творчості в різних компонентах має свою специфіку. Наприклад, на рівні когнітивного компонента етнопедагогічної компетентності етнопедагогічна творчість виявляється у творчому оперуванні етнопедагогічними фактами, осмисленні теоретичних підходів до трактування досвіду народної педагогіки, виявленні прихованих властивостей педагогічної дійсності, поглибленні аналізу педагогічних ситуацій, моделюванні розв'язання сформульованих педагогічних завдань з урахуванням здобутків народної педагогічної культури тощо. Етнопедагогічна творчість на рівні операційнотехнологічного компонента етнопедагогічної майстерності передбачає творче застосування етнопедагогічних знань під час розв'язання нестандартних педагогічних завдань, в інноваційній та дослідницькій діяльності, у процесі педагогічного спілкування, створення позитивного професійного іміджу тощо. Отже, етнопедагогічна творчість може розглядатись як елемент різних компонентів етнопедагогічної компетентності i як показник iï сформованості.

Загалом же етнопедагогічну творчість можна визначити як різновид педагогічної творчості, що передбачає нестандартне оперування вчителя-вихователя етнопедагогічною інформацією з метою створення оптимальних умов для формування творчої особистості учнів, вихованців, організації діалогічного педагогічного спілкування, удосконалення організації педагогічного процесу, забезпечення самореалізації та творчого довголіття педагога в умовах сучасного полікультурного суспільства.

Керуючись акмеологічними положеннями щодо педагогічної творчості, розробленими А. Марковою [3, с.87], ми вирізняємо два значення етнопедагогічної творчості. Етнопедагогічна творчість у вузькому значенні- це процес і результат знаходження принципово нових прийомів, засобів, методів, принципів, технологій навчання і виховання на основі опрацювання етнопедагогічного матеріалу. У широкому значенні етнопедагогічна творчість спрямована на професійне оперування вчителем-вихователем етнопедагогічною інформацією в сучасних умовах, творче застосування традиційних засобів, прийомів, методів 
навчання і виховання дітей, урахування національної належності вихованців та їхніх батьків у змісті та формах виховної роботи, у процесі організації педагогічного спілкування, використання етнопедагогічних матеріалів у процесі розвитку творчих здібностей дітей та в ході власного професійного вдосконалення.

Етнопедагогічна творчість в обох значеннях як складник та показник етнопедагогічної компетентності виявляється в педагогічній майстерності вчителя початкових класів, що зумовлено, передовсім, її причетністю до педагогічної творчості.

I. Зязюн розглядав педагогічну майстерність як умову і «засіб реалізації особистості вчителя, його позиції, творчого потенціалу» $[2$, с. 136]. У контексті педагогічної майстерності педагогічна творчість, а значить і етнопедагогічна, виявляється на різних рівнях і в усіх іiі елементах: гуманістичній спрямованості діяльності вчителя, професійній компетентності педагога, педагогічних здібностях та педагогічній техніці [4, с. 30-35].

Педагогічна й етнопедагогічна творчість у сфері гуманістичної спрямованості діяльності вчителя початкових класів реалізується на рівні розуміння дитини, іiі стану, прагнень, пізнавальних можливостей, усвідомлення іiі неповторності й оригінальності, прийняття дитини будь-якої національності, раси; творчої спрямованості професійної діяльності, спрямованості на оволодіння здобутками народної педагогічної культури та творче їх застосування в навчально-виховному процесі (хоча б у визначенні мети, завдань та змісту різних напрямів виховання сучасних дітей, застосування традиційних методів i прийомів спонукання дітей до різних видів діяльності); прагненні розкрити творчі здібності різних учнів тощо.

Професійна компетентність учителя початкових класів передбачає творче оперування матеріалами різних складників народної педагогіки (родинознавства, народного дитинознавства, народного виховання, народної дидактики, народної педагогічної деонтології); відкритість до інновацій, спроможність до застосування в педагогічному процесі традиційних методів, прийомів і засобів навчання і виховання в межах інноваційних технологій; здатність до одухотворення знань, застосування з цією метою народних творів, зокрема й дитячого фольклору (потішок, казок, небилиць, загадок, пісень, ігор, закличок, лічилок, примовок, мирилок, жартів, танців тощо); плідний аналіз праць відомих педагогів, мислителів про народну педагогіку.

Уважність, гнучкість мислення, кмітливість, креативність, які виявляються у кращому розумінні, трактуванні поведінки вихованців, налагодженні з ними контактів, емоційному і виразному викладі навчального матеріалу, організації діяльності дітей, творчій активності, творчому професійному мисленні, оптимізмі, самореалізації у творчій діяльності тощо, завжди позитивно оцінювались у поведінці вчителя, наставника, вихователя. Аналіз етнопедагогічної літератури 3 цього питання сприяє зорієнтованості фахівців на самовдосконалення, розвиток певних груп педагогічних здібностей.

У сфері педагогічної техніки на прикладі народної творчості реалізується натхненність у подачі навчального матеріалу, артистизм, здатність до творчого самопочуття на уроках і в позаурочний час, бачення педагогічної проблеми та альтернативи у іiі розв'язанні, застосування відомих у народній педагогіці прийомів зосередження уваги дітей, способів розподілу ролей у грі, творчого перетворення професійного середовища, плекання творчого стилю роботи тощо.

Експериментальне дослідження проблеми формування етнопедагогічної компетентності в майбутніх учителів початкових класів показало, що студенти 3 вищим рівнем сформованості етнопедагогічної компетентності схильні до педагогічної творчості, 
мають гнучкість в оперуванні інформацією полікультурного змісту, впевненіше керуються принципами педагогічного такту під час спілкування з учнями та їхніми батьками представниками різних національностей, комфортніше себе почувають у багатокультурному учнівському середовищі під час нестандартних форм педагогічної роботи.

Отже, формування творчої особистості педагога $\epsilon$ потребою часу та відповідає вимогам компетентнісного підходу в освіті. Становлення творчої особистості майбутнього вчителя початкових класів в умовах полікультурного суспільства передбачає формування у студента етнопедагогічної творчості. Етнопедагогічна творчість як елемент і показник етнопедагогічної компетентності вчителя початкових класів передбачає здатність фахівця застосовувати здобутки етнопедагогіки задля створення творчого самопочуття, організації діалогічного педагогічного спілкування, удосконалення навчально-виховного процесу, зокрема й із метою формування творчої особистості дитини, створення нових технологій, систем навчання і виховання тощо.

Перспективами вивчення проблеми є розгляд питань удосконалення етнопедагогічної творчості майбутніх фахівців у галузі початкової освіти у процесі формування в них інших видів педагогічної компетентності.

\section{Література}

1. Етнонаціональна структура українського суспільства: [довідник] / Свтух В.Б., Трощинський В. Г., Галушко К. Ю., Чернова К. О. - Київ : Наукова думка, 2004. - 342 с. 2. Зязюн І. А. Педагогіка добра: ідеали і реалії / Іван Андрійович Зязюн. - Київ : МАУП, 2000. - 312 с. 3. Маркова А. К. Психологический анализ профессиональной компетентности учителя / А. К. Маркова // Советская педагогика. - 1990. - №8. - С.82 - 88. 4. Педагогічна майстерність: [навч. посіб.] / [І. А. Зязюн, Л. В. Крамущенко, І. Ф. Кривонос та ін.]; за ред. І. А. Зязюна. - Київ : Вища школа, 2004. - 422 с.

УДК 372.47:510.5

Олександра Шаран, Володимир Шаран

\section{ВИКОРИСТАННЯ АЛГОРИТМІЧНОГО ПІДХОДУ У ПРОЦЕСІ ВИВЧЕННЯ КУРСУ «ТЕОРІЯ ТА МЕТОДИКА ФОРМУВАННЯ ЕЛЕМЕНТАРНИХ МАТЕМАТИЧНИХ УЯВЛЕНЬ»}

Шаран О. В., Шаран В. Л. Використання алгоритмічного підходу у процесі вивчення курсу «Теорія та методика формування елементарних математичних уявлень».

У статті розглянуто суть алгоритмічного підходу, описано технологію його використання на заняттях 3 «Теорії та методики формування елементарних математичних уявлень». Автори наголошують, що алгоритмізація сприяє формуванню професійних навичок та може бути засобом навчання творчого мислення студентів - майбутніх фахівців дошкільної освіти.

Ключові слова: алгоритмічний підхід, алгоритми, мислення, навчальний процес, студенти, математичні уявлення, дошкільна освіта.

Шаран А. В., Шаран В. Л. Использование алгоритмического подхода в процессе изучения курса «Теория и методика формирования элементарных математических представлений».

В статье рассмотрена суть алгоритмического подхода, описана технология его использования на занятиях по «Теории и методика формирования элементарных 